\title{
The role of micronutrients on COVID-19 treatment for adults, children and elderly
}

\author{
O papel dos micronutrientes no tratamento da COVID-19 para adultos, crianças e idlosos \\ El papel de los micronutrientes en el tratamiento de COVID-19 para adultos, niños y ancianos
}

Received: 01/22/2021 | Reviewed: 01/26/2021 |Accept: 01/26/2021 | Published: 02/04/2021

\author{
Sandra Lúcia Fernandes \\ ORCID: https://orcid.org/0000-0001-5119-8908 \\ Associação Brasileira de Nutrologia, Brazil \\ E-mail: sandranut@yahoo.com.br \\ Ana Lúcia dos Anjos Ferreira \\ ORCID: https://orcid.org/0000-0002-5267-1127 \\ São Paulo State University, Brazil \\ E-mail: ferreira@fmb.unesp.br \\ Eline de Almeida Soriano \\ ORCID: https://orcid.org/0000-0003-2080-9344 \\ Associação Brasileira de Nutrologia, Brazil \\ E-mail: dra.eline @abran.org.br \\ Simone Chaves de Miranda Silvestre \\ ORCID: https://orcid.org/0000-0002-4666-2056 \\ Associação Brasileira de Nutrologia, Brazil \\ E-mail: scmir@uol.com.br \\ Carlos Alberto Nogueira-de-Almeida \\ ORCID: https://orcid.org/0000-0003-1272-4404 \\ Universidade Federal de São Carlos, Brazil \\ E-mail: dr.nogueira@me.com \\ Nelson Iucif Junior \\ ORCID: https://orcid.org/0000-0001-8583-9304 \\ Associação Brasileira de Nutrologia, Brazil \\ E-mail: ngerianutro@uol.com.br \\ Rodrigo Fernandes Weyll Pimentel \\ ORCID: https://orcid.org/0000-0003-0101-0190 \\ University Hospital Complex Professor Edgard Santos, Brazil \\ Federal University of Bahia, Brazil \\ E-mail: rodrigo.pimentel@ebserh.gov.br \\ Isolda Prado de Negreiros Nogueira Maduro \\ ORCID: https://orcid.org/0000-0002-6822-2932 \\ Universidade do Estado do Amazonas, Brazil \\ E-mail: isoldaprado@yahoo.com.br
}

\begin{abstract}
Introduction: Coronaviruses have been shown to infect humans. Such viral types were the causing agents of the outbreaks of the Severe Acute Respiratory Syndrome. Specific malnutrition leads to deleterious effects on immunity. Thus, the treatment of these deficiencies, both in outpatients and inpatients with suspected SARS-CoV-2, could help the immune system to play its role in an optimal level of defense. Objective: This review aims to discuss the beneficial effects of treatments for specific deficiencies related to vitamins A, D, C, zinc, and selenium. Methods: This is a narrative review. The search included research in electronic databases and manual search for citations in LILACS and MEDLINE, developed between June 2020 and December 2020. Results and Discussion: The immune system undergoes changes throughout life and depends on an adequate supply of nutrients. Some micronutrients of the diet have very specific roles to develop and maintain an effective immune system. The most needed micronutrients to support immunocompetence are vitamins A, C, D, E, B2, B6, B12, folic acid and the minerals zinc, selenium, iron, magnesium, and copper. The diet is expected to supply an adequate amount of these nutrients. However, the daily intake of these necessary substances may be greater during infection. This is particularly important in acute respiratory tract infections. Conclusion: This article demonstrates the importance of maintaining a balanced diet, with adequate intake of micronutrients, especially when it comes to the COVID-19 pandemic.
\end{abstract}

Keywords: Coronavirus infections; Micronutrients; Adult; Aged; Child; Avitaminosis.

\section{Resumo}

Introdução: Os coronavírus têm sido demonstrados como causadores de infecções em humanos. Esses tipos virais foram os agentes causadores dos surtos da Síndrome Respiratória Aguda Grave. Desnutrição específica leva a efeitos deletérios na imunidade. Assim, o tratamento dessas deficiências, tanto em ambulatórios quanto em pacientes 
internados com suspeita SARS-CoV-2, poderia ajudar o sistema imunológico a desempenhar seu papel em um nível ideal. Objetivo: Esta revisão tem como objetivo discutir os efeitos benéficos dos tratamentos para deficiências específicas relacionadas às vitaminas A, D, C, zinco e selênio. Métodos: Método: Trata-se de uma revisão narrativa. A pesquisa incluiu pesquisa em bancos de dados eletrônicos e busca manual de citações em LILACS e MEDLINE, desenvolvida entre junho de 2020 e dezembro de 2020. Resultados e Discussão: O sistema imunológico sofre mudanças ao longo da vida e depende de um fornecimento adequado de nutrientes. Alguns micronutrientes da dieta têm papéis muito específicos para desenvolver e manter um sistema imunológico eficaz. Os micronutrientes mais necessários para suportar a imunocompetência são as vitaminas A, C, D, E, B2, B6, B12, ácido fólico e os minerais zinco, selênio, ferro, magnésio e cobre. Espera-se que a dieta forneça uma quantidade adequada desses nutrientes. No entanto, a ingestão diária dessas substâncias pode ser maior durante infecções. Isso é particularmente importante em infecções agudas do trato respiratório. Conclusão: Este artigo demonstra a importância de manter uma dieta equilibrada, com ingestão adequada de micronutrientes, especialmente quando se trata da pandemia por COVID-19.

Palavras-chave: Infecções por coronavirus; Micronutrientes; Adulto; Idoso; Criança; Deficiência de vitaminas.

\section{Resumen}

Introducción: Se ha demostrado que los coronavirus causan infecciones en humanos. Estos tipos virales fueron los causadores de brotes de Síndrome Respiratorio Agudo Severo. La desnutrición específica conduce a efectos nocivos sobre la inmunidad. Por lo tanto, el tratamiento de estas deficiencias, tanto en clínicas ambulatorias como en pacientes hospitalizados con sospecha de SARS-CoV-2, podría ayudar al sistema inmunitario a desempeñar su papel a un nivel ideal. Objetivo: Esta revisión tiene como objetivo discutir los efectos beneficiosos de los tratamientos para deficiencias específicas relacionadas con las vitaminas A, D, C, zinc y selenio. Métodos: Método: Esta es una revisión narrativa. La investigación incluyó investigaciones en bases de datos electrónicas y búsqueda manual de citas en LILACS y MEDLINE, desarrolladas entre junio de 2020 y diciembre de 2020. Resultados y discusión: El sistema inmunitario sufre cambios a lo largo de la vida y depende de un suministro adecuado de nutrientes. Algunos micronutrientes en la dieta tienen funciones muy específicas en el desarrollo y mantenimiento de un sistema inmunológico eficaz. Los micronutrientes más necesarios para apoyar la inmunocompetencia son las vitaminas A, C, D, E, B2, B6, B12, ácido fólico y los minerales zinc, selenio, hierro, magnesio y cobre. Se espera que la dieta proporcione una cantidad adecuada de estos nutrientes. Sin embargo, la ingesta diaria de estas sustancias puede ser mayor durante las infecciones. Esto es particularmente importante en las infecciones agudas del tracto respiratorio. Conclusión: Este artículo demuestra la importancia de mantener una dieta equilibrada, con una ingesta adecuada de micronutrientes, especialmente cuando se trata de la pandemia por COVID-19.

Palabras clave: Infecciones por coronavirus; Micronutrientes; Adulto; Ancianos; Niño; Deficiencia de vitaminas.

\section{Introduction}

Coronaviruses (CoVs) belong to the Coronaviridae family and to some subfamilies, namely: $\alpha$-coronavirus, $\beta$ coronavirus, $\gamma$-coronavirus, and $\delta$-coronavirus. These viruses mainly cause infections in birds and mammals, but they have been shown to infect humans in recent decades. The $\beta$-coronavirus group has particularly shown higher lethality in human beings when crossing the barrier between species. Such viral types were the causing agents of the outbreaks of the Severe Acute Respiratory Syndrome (SARS-CoV) in 2002, as well as the Middle East Respiratory Syndrome (MERS-CoV) in 2012. A new influenza-like coronavirus (SARS-CoV-2), related to MERS and SARS coronaviruses, was recently found in late 2019 in China and evidence of human-to-human transmission has been confirmed (L. Zhang \& Liu, 2020).

Specific malnutrition leads to deleterious effects on immunity. Thus, the treatment of these deficiencies, both in outpatients and inpatients with suspected SARS-CoV-2, could help the immune system to play its role in an optimal level of defense. Based on current literature related to COVID-19 and other diseases caused by viruses, this study aims to discuss the beneficial effects of treatments for specific deficiencies related to vitamins A, D, C, zinc, and selenium. Other micronutrients also play a large role in the immune system but will not be included in this work.

Some nutritional interventions on viral targets are shown in the Table 1. 
Table 1. General nutritional support treatments for viral infections.

\begin{tabular}{ll}
\hline \multicolumn{1}{l}{ Nutritional Interventions } \\
\hline Options & Focused on the virus and related functions \\
\hline Vitamin A & Measles virus, human immunodeficiency virus, avian coronavirus \\
B-complex Vitamins & MERS-CoV; avian coronavirus (ventilator-induced lung injury) \\
Vitamin C & Bovine coronavirus (lower respiratory tract infections) \\
& \\
Vitamin D & Bovine coronavirus \\
Vitamin E & Coxsackievirus, bovine coronavirus \\
& \\
Omega-3 polyunsaturated fatty acids (PUFA) & Influenza virus, human immunodeficiency virus \\
Selenium & Influenza virus, avian coronavirus; viral mutations \\
Zinc & Measles virus, SARS-CoV \\
Iron & Viral mutations \\
\hline MERS-CoV: Middle East respiratory syndrome coronavirus; SARS-CoV: Severe acute respiratory syndrome coronavirus. \\
\hline
\end{tabular}

Source: Adapted from Zhang \& Liu, 2020 (L. Zhang \& Liu, 2020).

\section{Methodology}

This is a narrative review. Narrative reviews are broad publications appropriate to describe and discuss the development or "state of the art" of a given subject, from a theoretical or contextual point of view. They basically constitute the analysis of the literature published in books, articles of printed and/or electronic journals, in the interpretation and personal critical analysis of the author. This category of articles plays a fundamental role for continuing education, as they allow the reader to acquire and update knowledge on a specific theme in a short period of time (Nagib et al., n.d.).

The search for articles included research in electronic databases and manual search for citations in the publications initially identified. The electronic databases studied were LILACS (Latin American and Caribbean Literature on Health Sciences), and international literature on Health Sciences (MEDLINE). In MEDLINE, keyword in English was used, while in LILACS keywords were used in Portuguese, English and Spanish. The search was developed between June 2020 and December 2020. For the search of the articles, we used the descriptors standardized by the Descriptors in Health Sciences: Coronavirus, COVID-19, micronutrients, vitamins, minerals, child, elderly and adults.

The titles and abstracts of all articles identified in the electronic search were reviewed. When possible, studies that seemed to meet the criteria for their inclusion were obtained in full. The inclusion criteria were: being research articles, case studies and systematic reviews in journals.

\section{Results and Discussion}

\subsection{Vitamin A}

Vitamin A is a fat-soluble substance and its precursor, $\beta$-carotene, is derived from vegetables. There are three active forms in the body: retinol, retinal, and retinoic acid. In the active form of retinol, foods considered as the best sources of vitamin A are animal-based, such as viscera (mainly liver, cod liver oils, and giant sole) and egg yolks. Carotenoids are found in dark green leafy vegetables and yellow-orange vegetables and fruits (mango, papaya, pumpkin, carrot, mango, sweet potato, spinach, mustard, and cabbage). Palm fruits such as bacuri, bocaiúva, tucumã, macaúba and pupunha are also important 
sources of carotenoids and have excellent bioavailability. Buriti and oil palm are considered the richest sources of pro-vitamin A found in Brazil(Nogueira et al., 2019). The multivitamins currently available have about 55\% to $167 \%$ of the Recommended Dietary Allowance (RDA).

Defenses against infections depend on an adequate supply of vitamin A. The mechanism by which vitamin A inhibits measles replication, for example, occurs in part by stimulating the innate immune response (Trottier et al., 2009). The deficiency of this nutrient is strongly related to measles and diarrhea (Kańtoch et al., 2002). In addition, measles can become severe in children with vitamin A deficiency. Supplementation of this micronutrient has reduced morbidity and mortality in several infections, such as HIV, malaria, measles, measles-associated pneumonia, and diarrhea (Semba, 1999). Using an experimental model, a study showed that infectious bronchitis caused by a type of coronavirus was more pronounced in the presence of deficient intake when compared to an adequate diet of vitamin A. (West et al., 1992)

Adverse results during viral infections have been associated with low levels of vitamin A (in addition to E, B6, B12, and trace elements such as zinc and selenium) (Semba, 1999). This hypothesis was explained in a recent literature review, which proposed that vitamin A (and vitamins D, B, C, omega-3 fatty acids, selenium, and zinc) should be considered for patients with COVID-19 (Barazzoni et al., 2020; L. Zhang \& Liu, 2020).

Although it is important to treat micronutrient deficiencies, there is still no evidence that supraphysiological doses of vitamin A can prevent COVID-19 or improve patients with such coronavirus(Barazzoni et al., 2020). In view of the above considerations, we suggest that the provision of daily doses of vitamins and trace elements should be ensured to malnourished patients at risk of becoming infected or already infected with COVID-19 in order to maximize defense.

It should also be noted that there is a risk of toxicity if vitamin $\mathrm{A}$ is ingested in high doses. Thus, it is not recommended to take super-doses of this micronutrient or its precursor ( $\beta$-carotene). The administration of high doses of $\beta$ carotene $(\geq 30 \mathrm{mg} / \mathrm{d})$ or vitamin $\mathrm{A}(\geq 25,000 \mathrm{IU} / \mathrm{d})$ has been particularly associated with increased mortality (from all causes) and the incidence of various types of cancer (Bjelakovic et al., 2008; Schwingshackl et al., 2017).

The daily vitamin-A RDA target of healthy individual is $700 \mathrm{mcg} / \mathrm{d}$ for women and $900 \mathrm{mcg} / \mathrm{d}$ for men ("Diet. Ref. Intakes Vitam. A, Vitam. K, Arsenic, Boron, Chromium, Copper, Iodine, Iron, Manganese, Molybdenum, Nickel, Silicon, Vanadium, Zinc," 2001). This reference value is reported as an equivalent to retinol activity (mcg/RAE) and can be converted into international units.

\subsection{Vitamin C (Ascorbic Acid)}

Vitamin $\mathrm{C}$ is an essential micronutrient for collagen biosynthesis and a cofactor in the biosynthesis of catecholamines, L-carnitine, cholesterol, amino acids, and some peptide hormones. The lack of vitamin C causes scurvy, which is a pathological condition that leads to blood vessel fragility and damage to connective tissue due to failure in collagen production. Finally, such deficiency can lead to death as a result of a general breakdown (Grosso et al., 2013).

Vitamin C can prevent susceptibility of lower respiratory tract infections under certain conditions, as well as exercising physiological functions to decrease flu-like symptoms due to antihistamine action (L. Zhang \& Liu, 2020) of such vitamin. Additionally, vitamin $\mathrm{C}$ can also reactivate other captors of reactive oxygen species, such as glutathione and alphatocopherol, by donating an electron to these compounds and allowing their function, presenting an antioxidant action (Teng et al., 2018).

Vitamin $\mathrm{C}$ deficiency in the general population is rare since this substance is abundant in nature. The recommended daily needs vary between countries, ranging from 45mg/d to 110mg/d (Carr et al., 2016). In Brazil, the RDA standards adopted are $75 \mathrm{mg} / \mathrm{d}$ for women and $90 \mathrm{mg} / \mathrm{d}$ for men. The main sources are citrus fruits and raw vegetables (Machado et al., 2009). 
Three controlled studies in humans reported that there was a significantly lower incidence of pneumonia in groups of patients supplemented with vitamin C. (L. Zhang \& Liu, 2020) By assessing high vitamin-C supplementation for patients with severe respiratory distress syndrome (ARDS), a recent study considered such supplementation as a safe treatment option in relation to the secondary outcomes analyzed (lower mortality after 28 days in the ICU, days without ICU and days without hospital) (Zaatari et al., 2020). In a systematic review, intake of $1 \mathrm{~g} / \mathrm{d}$ of ascorbic acid reduced the flu's duration (8\% in adults and $14 \%$ in children) (Hemilä \& Chalker, 2013). The authors did not recommend routine supplementation due to the lack of effect on the incidence of colds and flu. However, the severity of the flu has been reduced with the regular use of vitamin C and can be considered a safe and low-cost treatment (Hemilä \& Chalker, 2013).

Regarding its use for treating COVID-19, a recent literature review suggests that vitamin C could be an option for a supportive treatment, although further clinical studies and systematic reviews are needed (L. Zhang \& Liu, 2020). For individuals at risk of respiratory viral infections, the use of high oral doses of vitamin C (up to $2 \mathrm{~g} / \mathrm{d}$ ) may be indicated.

\subsection{Vitamin D (Cholecalciferol)}

Vitamin D is a fat-soluble substance, derived from sterols, called pro-vitamins. The substrate of the active form can be obtained by endogenous means (D3 or cholecalciferol) or diet (D2 or ergosterol), and activated by the action of UV-B rays on the skin (Machado et al., 2009).

The role of vitamin D has been widely studied in the immune response. Several studies show that cholecalciferol increases the expression of antibacterial peptides, which contributes to a better host immune response (Bruce et al., 2010; Hewison, 2010).

In patients with COVID-19, SARS-CoV-2 binds to receptors for the angiotensin-converting enzyme 2 (ACE2) in the respiratory tract of infected patients, thereby entering the host cells. The active form of vitamin $\mathrm{D}$, calcitriol $(1,25$ dihydroxycholecalciferol), has a protective effect via modulation of the expression of these ACE2 receptors in lung tissue. Serum vitamin D levels are essential for optimizing the immune response. Deficiency of this vitamin is associated with an increased incidence of viral infections of the respiratory tract and acute lung injury (Ebadi \& Montano-Loza, 2020).

Vitamin D receptors (VDRs) are widely distributed in respiratory epithelial cells and immune cells (B cell, T cell, macrophages, and monocytes). 25-hydroxyvitamin D (25OHD), which is the main circulating form of vitamin $\mathrm{D}$, can be converted to the active form 1,25-dihydroxyvitamin D in the bronchial epithelium and immune cells. The $1 \alpha$-hydroxylase (CYP27B1), which is necessary for activating vitamin D, is induced by several stimuli, including cytokines and toll-like receptors in the respiratory tract. However, adequate serum levels of 25OHD are necessary to increase levels of 1,25dihydroxyvitamin D and, therefore, improve the immune response to respiratory virus infections (Ebadi \& Montano-Loza, 2020).

Type-II pneumocytes are the primary target of coronaviruses and ACE2 receptors are highly expressed in these cells. The impaired function of type-II pneumocytes decreases the level of the surfactant and increases the surface tension in COVID-19. The 1,25-dihydroxyvitamin D metabolites have been reported to stimulate the synthesis of surfactants in these cells. Both in vitro culture of human fetal and adult type-II alveolar cells with 1,25-dihydroxyvitamin D increased the VDR and the expression of protein B associated with the surfactant. This is a lipid-based protein of the pulmonary surfactant, which indicates the potential of vitamin D to reduce the surface tension in COVID-19 (Ebadi \& Montano-Loza, 2020).

The relevance of vitamin $\mathrm{D}$ in this context is based on the growing evidence that its supplementation and restoration to normal values in infected patients can improve immune recovery. In this way, this substance reduces inflammation levels, improves immune activation and increases immunity against pathogens (Caccialanza et al., 2020).

In addition, it is important to pay attention to the higher lethality of COVID-19 in those older than 60 years old. In this 
population, we found a high prevalence of hypovitaminosis D. In addition to that characteristic, less sun exposure of individuals due to social isolation at home increasingly contributes to reduce their serum levels, which compromises the immune response of the elderly (AC et al., 2011; Gombart et al., 2020).

A systematic meta-analysis review carried out by Martineau et al. found that the use of vitamin D at doses between 800 and 2,000 IU/d reduced the rate of respiratory viral infections, especially among individuals with baseline serum levels below $10 \mathrm{ng} / \mathrm{mL}$ (25 nmol / L) (Martineau et al., 2017). There was also a positive result, but with less impact, in those groups with initial serum levels around $20 \mathrm{ng} / \mathrm{mL}(24 \mathrm{nmol} / \mathrm{L})$ and $30 \mathrm{ng} / \mathrm{mL}(75 \mathrm{nmol} / \mathrm{L})$.

There are few cases of hypersensitivity to vitamin D. This condition is one of the contraindications for supplementation, in addition to mutation in the CYP24A1 gene or the presence of sarcoidosis. There is no evidence of an increased incidence of nephrolithiasis, and doses between 2,000 IU/d or 4,000 IU/d are considered safe(Zemb et al., 2020) .

Thus, in the presence of a 25OHD deficit, cholecalciferol should be promptly supplemented according to the results of serum levels. The recommended oral replacement should be at a dose of 50,000 IU/week, if serum levels of $25 \mathrm{OHD}<20$ $\mathrm{ng} / \mathrm{mL}$, and at 25,000 IU/week, if 25OHD $\geq 20$ and $30 \mathrm{ng} / \mathrm{mL}$ (AC et al., 2011).

According to the RDA, daily intake should be between 600 and $800 \mathrm{IU} / \mathrm{d}$ (AC et al., 2011). The main dietary sources are fish with a high fat content (salmon, sardines), egg yolk, liver, milk and its derivatives (Machado et al., 2009).

\subsection{Zinc}

Zinc is an essential and determinant trace element for maintaining innate and adaptive immune function (Calder et al., 2020). Although the mechanism is uncertain, zinc antiviral activity has been reported by inhibiting viral replication in cell culture(Zumla et al., 2020), which inhibits coronavirus RNA polymerase activity (te Velthuis et al., 2010) and improves the anti-viral action of cytokines and human interferon (IFN- $\alpha$ ) (Barnard et al., 2007; Read et al., 2019; Uchide et al., 2002).

It is estimated that the global zinc deficiency is around $17 \%$ to $20 \%$, especially in developing countries in Africa and Asia (Kumssa et al., 2015; Wessells \& Brown, 2012). In developed countries, zinc deficiency occurs in the elderly, vegans and vegetarians and in patients with chronic diseases, such as inflammatory bowel disease and cirrhosis (Himoto \& Masaki, 2018; Siva et al., 2017). The plasma zinc concentration ranges from 10 to $18 \mathrm{mcM}$ (Rükgauer et al., 1997). Its action against the coronavirus (SARS-CoV) was evidenced by an in vitro study (te Velthuis et al., 2010). Studies on the new coronavirus are not yet available in the literature.

The zinc content varies between foods $(0.002 \mathrm{mg} / 100 \mathrm{~g}$ of egg white, $1 \mathrm{mg} / 100 \mathrm{~g}$ of chicken and $75 \mathrm{mg} / 100 \mathrm{~g}$ of oysters, for example). Shellfish, oysters, red meats, liver, offal, and eggs are considered the best sources of this trace element. Nuts and legumes are relatively good sources of this micronutrient (Mafra \& Cozzolino, 2004). It is worth mentioning that the intestinal absorption of zinc from plant foods is not as efficient as the absorption of the element in animal food. Therefore, vegetarians may need up to $50 \%$ more zinc in the diet than non-vegetarians. The upper limit for zinc intake is $40 \mathrm{mg} / \mathrm{d}$. Consuming more than this amount can increase the risk of copper deficiency, which blocks the intestinal absorption of copper ("Diet. Ref. Intakes Vitam. A, Vitam. K, Arsenic, Boron, Chromium, Copper, Iodine, Iron, Manganese, Molybdenum, Nickel, Silicon, Vanadium, Zinc," 2001).

The supply of micronutrients, including zinc, is an integral part of nutritional support, as stated in the 2009 guidelines (Singer et al., 2009). Several micronutrients are consumed during the inflammatory response, which makes it difficult to interpret values below the reference level. On the other hand, recent evidence seems to show that recurrent sepsis is associated with persistently low serum zinc concentration (Hoeger et al., 2017). In conditions of chronic and acute deficiency, replacing micronutrients is recommended. For ethical reasons, Nutritional Therapy studies without micronutrient supplementation cannot be performed, so these recommendations do not have a strong degree of scientific evidence (Barazzoni et al., 2020; Singer et 
al., 2019).

Despite the difficulty in interpreting the real clinical translation of low levels of zinc in patients with inflammation, a recent literature review recommends that ingestion of this trace element follows the same recommendation as the RDA in order to support optimal immune function. Therefore, zinc consumption should be $8 \mathrm{mg} / \mathrm{d}$ in women and $11 \mathrm{mg} / \mathrm{d}$ in men 24 . In case of acute diarrhea, a greater oral zinc supplementation is recommended from 20 to $40 \mathrm{mg} / \mathrm{d}$ (Kostermans et al., 2014; Maret \& Sandstead, 2006).

\subsection{Selenium}

During viral infections, reactive oxygen, and nitrogen species (called free radicals) are abundantly produced. These substances overload the antioxidant defense system and induce redox state unbalance imbalance, which results in (oxidative stress). Such a scenario provides and amplifies viral replication and unbalances the host's immune response. Among the nutrients involved in viral infection, selenium plays an important role on antioxidant defense and virus pathogenicity (Guillin et al., 2019; Hoffmann \& Berry, 2008).

Recent studies have shown that selenium deficiency is associated with worse outcomes in patients with COVID-19 (Moghaddam et al., 2020; J. Zhang et al., 2020). Despite this association, it is not widely known how the deficiency of this micronutrient can interfere the disease course.

The recommended daily intake of selenium is $55 \mathrm{mcg} / \mathrm{d}$ according to the RDA (Amaya-Farfan et al., 2001; Padovani et al., 2006). Higher doses of selenium (200 mcg/d) may act as an adjuvant in the treatment of infections treatment, however, they cannot be used for a long time period (Krinsky et al., 2000).

The selenium content in various foods such as Brazil nuts can vary depending on the place of cultivation place. The consumption of three Brazil nuts (approximately $15 \mathrm{~g}$ of selenium) corresponds to the daily intake recommendation recently suggested by Lima et al. (Lima et al., 2019).

Based on the best available evidence, the use of daily doses of $55 \mathrm{mcg}$ of selenium can be indicated, and doses above this RDA should be evaluated according to the serum level. This dose can be found in certain multivitamins available in Brazilian territory.

\subsection{Considerations and recommendations on micronutrient supplementation for improving the preventive immune response of children}

In Brazil, as well as in many parts of the world, children face a chronic problem of hidden hunger (Ruel-Bergeron et al., 2015). Despite the absence of data of Brazilian national scope, regional studies have shown high prevalence of micronutrient deficiencies (Fidelis \& Osório, 2007; Pedraza et al., 2013). The nutritional transition results in a diet enriched in fat and sugar and poor in several other nutrients, which is associated to a higher risk of infections, impaired immune system and growth deficits (Corvalán et al., 2017).

In addition to health impacts, micronutrients play an important role as immunonutrients and it is plausible to believe, even without specific Brazilian studies, that our children have some damage to their immunity as a result of the hidden hunger process (Ströhle \& Hahn, 2009). Here it is worth mentioning the following micronutrients and their immunological functions recognized in childhood:

Vitamin D - It acts on the innate and adaptive mechanisms of immunity. It also plays a role in cells with antigens (which are connected to the two systems mentioned above) and has an eminently stimulatory effect.

Vitamin $\mathbf{E}$ - It amplifies the function of the T cell, which promotes the integrity of the membrane and reduces the production of macrophage suppressive factors. 
Zinc - The deficiency of this micronutrient leads to losses in several functions, namely: proliferation of lymphocytes, production of IL2, activity of NK cells, phagocytic capacity of macrophages, functional capacity of neutrophils, maturation of $\mathrm{T}$ cell and intracellular regulation of lymphocytic apoptosis.

Vitamin A - It acts on the cellular differentiation of immune cells, it is necessary for an adequate response to infectious processes and reduces the susceptibility to infections.

Iron - Indispensable for cell multiplication and a fundamental component of hemoglobin for oxygen transport. Anemia is linked to greater susceptibility to most infectious processes, as well as their recovery.

Based on 12 studies involving children under 5 years of age with diarrhea, the research carried out by the WHO in 2001 can be mentioned as an example of successful nutritional intervention. The results showed that simple zinc supplementation led to a $25 \%$ reduction in diarrheal episodes and the evolution to chronic conditions. This effect lasted for 3 months after supplementation (Organization \& UNICEF, 2006). Thus, since 2006, UNICEF has recommended zinc supplementation to prevent and treat diarrhea (Organization, 2010), considered a paradigm of pediatric infectious disease (Fischer Walker et al., 2009).

In fact, zinc supplementation has been shown to be effective to prevent other infections, such as those of the upper respiratory ones (URI). A meta-analysis carried out in 1999 showed a 41\% reduction in the incidence of pneumonia among supplemented individuals (Bhutta et al., 1999). It is currently considered that zinc supplementation should include all children at risk, especially those in countries that have high rates of morbidity and mortality from infectious diseases (Bhutta et al., 1999).

An important measure to control hidden hunger was developed in the 1990s. It is a sachet with granular content, which is added to one of the meals. Micronutrients in dry form are prepared to prevent interaction between themselves and in such a way that there are almost no changes in the taste, color and texture of the foods to which they are added (Silva, 2017). The WHO also recommended its use in emergency situations, as it seems to be the case at this time (Organization, 2007). Systematic review conducted by Dewey et al. showed a positive effect of this strategy for reducing pediatric morbidity, especially among children at nutritional risk (Dewey et al., 2009). Brazil already has a program called Nutri-SUS that includes the preparation and distribution of sachets for certain groups of children (daycare centers that participate in Programa Saúde na Escola. (Health at School Program in a free English Translation). The details on this program are available on an official digital document (Farias et al., n.d.). At this point, an alternative could be expanding this program to the entire pediatric population.

\subsection{Considerations and recommendations on micronutrient supplementation for improving the preventive immune response of the elderly}

When it comes to care related to infectious diseases, special attention should be given to the elderly due to the high risk of viral infection and mortality in this population. In the COVID-19 pandemic, a high mortality rate has been observed both in Italian studies (83.7\%) and in older studies (22\%)(Abbatecola \& Antonelli-Incalzi, 2020; Leung, 2020), especially among patients over the age of 70 years.

The immune system undergoes changes throughout life, reaches a potentially ideal level in young adults, and declines when aging in a process called immunosenescence (Maggini et al., 2018; Pae \& Wu, 2017). Both innate and acquired immunity are affected and this immunosenescence is clinically characterized by greater susceptibility to infections, as well as to several degenerative diseases, particularly cancer, cardiovascular, neurological and autoimmune diseases, in addition to less response to vaccination (Crooke et al., 2019; Oh et al., 2019; Pawelec, 2018). As the risk and severity of infections vary according to immune competence, immunosenescence makes the elderly more vulnerable and more susceptible to serious 
infections (Oh et al., 2019; Pae \& Wu, 2017).

The immune function also depends on an adequate supply of nutrients to support the functions of the immune cells. This allows such cells to initiate effective responses against the attackers, to resolve the process and avoid any underlying chronic inflammation (Childs et al., 2019). Some micronutrients and components of the diet have very specific roles to develop and maintain an effective immune system for the development, maintenance and expression of the immune response (Childs et al., 2019; Maggini et al., 2018). Micronutrients are essential for the entire immune system and this is true for any age group, including the elderly population. The most needed micronutrients to support immunocompetence are vitamins A, C, D, E, B2, B6, B12, folic acid and the minerals zinc, selenium, iron, magnesium and copper (Gombart et al., 2020; Maggini et al., 2018).

However, micronutrient deficiencies are common in elderly people even in developed countries. It is estimated that $35 \%$ of people aged 50 and over in Europe, the USA and Canada have a deficiency of one or more micronutrients (Maggini et al., 2018). Such inadequate nutritional status can further compromise the immune function of the elderly and increase their risk of infection. On the other hand, the immune function can be improved by restoring deficient micronutrients to the recommended levels, thus increasing resistance to infection and enabling faster recovery during their onset (Gombart et al., 2020; Maggini et al., 2018).

The diet is usually expected to supply an adequate amount of these nutrients. However, in addition to certain populations having inadequate intake of micronutrients in the diet, the daily intake of these necessary substances to support immune function may be greater than the current recommended doses. Situations that raise these needs, such as an infection, cause a greater decrease in organic reserves, which makes supplementation with higher doses even more necessary (Gombart et al., 2020). This is particularly important in acute respiratory tract infections, which are a major cause of morbidity and mortality worldwide, illustrated by seasonal influenza epidemics and the current coronavirus outbreak (Oh et al., 2019).

Considering the elderly population is a high-risk group for micronutrient deficiency and needs to improve their immune response, we recommend the following doses of micronutrients.

Multivitamin and minerals - In addition to the diet, a multivitamin and trace element supplement that provides the recommended daily requirements for vitamins and trace elements, including vitamins A, B6, B12, C, D, E and folate, and the trace elements zinc, selenium, iron, magnesium and copper (Calder et al., 2020; Gombart et al., 2020).

Vitamin C - Doses $\geq 200 \mathrm{mg} / \mathrm{d}$ provide levels of blood saturation and support the reduction in risk, severity, and duration of upper/lower respiratory tract infections. During the infectious processes there is a greater demand for vitamin C. Thus, inpatients with viral infection should receive 1-2 g/d(Calder et al., 2020; Gombart et al., 2020).

Vitamin D - A study carried out in 20 European countries showed a negative correlation between the average levels of Vitamin D and the morbidity and the mortality caused by COVID-19 (Ilie et al., 2020). Daily vitamin D supplementation reduces the risk of acute respiratory tract infections and 2,000 IU/d is recommended in normal patients (Calder et al., 2020). Patients with COVID-19 and serum vitamin D levels below 20ng/mL should receive 100,000 IU followed by weekly doses of 50,000 IU until normalization (between 40-60 ng/mL) (Ebadi \& Montano-Loza, 2020).

Zinc - An intake of $8 \mathrm{mg} / \mathrm{d}$ for women and $11 \mathrm{mg} / \mathrm{d}$ for men must be guaranteed, up to $40 \mathrm{mg} / \mathrm{d}$. High doses do not seem to improve the immunity of elderly patients (Calder et al., 2020; Mocchegiani et al., 2013; Pae \& Wu, 2017).

\section{Final Considerations}

This article reviews the main micronutrients related to the immune system and their function, and it demonstrates the importance of maintaining a balanced diet, with adequate intake of these substances. Especially when it comes to the COVID19 pandemic, maintaining a well-functioning immunity is essential for preserving health. The literature still lacks good quality evidence to understand the effective participation of the most diverse micronutrients to control and balance the immune system 
and their interaction with SARS-CoV-2 infection.

Finally, we encourage that micronutrients are obtained through improvements in food quality by implementing adequate eating habits. This movement seems to be more efficient than the acquisition of these components by using oral supplements, which should be reserved for the cases of verified deficiencies.

Future studies that test micronutrient supplementation as a specific strategy for improvement of the immune system in patients with COVID-19 may bring better elucidation of the role of these nutrients for these population.

\section{References}

Abbatecola, A. M., \& Antonelli-Incalzi, R. (2020). COVID-19 Spiraling of Frailty in Older Italian Patients. Journal of Nutrition, Health and Aging, 24(5), 453-455. https://doi.org/10.1007/s12603-020-1357-9

Ac, R., Cl, T., Al, Y., \& Hb, D. V. (2011). Dietary Reference Intakes for Calcium and Vitamin D. In Dietary Reference Intakes for Calcium and Vitamin D. National Academies Press. https://doi.org/10.17226/13050

Amaya-Farfan, J., Domene, S. M. A., \& Padovani, R. M. (2001). Dri: Commented note of the new nutritional recommendations for dietary antioxidants. Revista de Nutricao, 14(1), 71-78. https://doi.org/10.1590/s1415-52732001000100010

Barazzoni, R., Bischoff, S. C., Breda, J., Wickramasinghe, K., Krznaric, Z., Nitzan, D., Pirlich, M., \& Singer, P. (2020). ESPEN expert statements and practical guidance for nutritional management of individuals with SARS-CoV-2 infection. Clinical Nutrition, 39(6), 1631-1638. https://doi.org/10.1016/j.clnu.2020.03.022

Barnard, D. L., Wong, M. H., Bailey, K., Day, C. W., Sidwell, R. W., Hickok, S. S., \& Hall, T. J. (2007). Effect of oral gavage treatment with ZnAL42 and other metallo-ion formulations on influenza A $\mathrm{H} 5 \mathrm{~N} 1$ and $\mathrm{H} 1 \mathrm{~N} 1$ virus infections in mice. Antiviral Chemistry and Chemotherapy, 18(3), 125-132. https://doi.org/10.1177/095632020701800302

Bhutta, Z. A., Black, R. E., Brown, K. H., Meeks Gardner, J., Gore, S., Hidayat, A., Khatun, F., Martorell, R., Ninb, N. X., Penny, M. E., Rosado, J. L., Roy, S. K., Ruel, M., Sazawal, S., \& Shankar, A. (1999). Prevention of diarrhea and pneumonia by zinc supplementation in children in developing countries: Pooled analysis of randomized controlled trials. Journal of Pediatrics, 135(6), 689-697. https://doi.org/10.1016/S0022-3476(99)70086-7

Bjelakovic, G., Nikolova, D., Simonetti, R. G., \& Gluud, C. (2008). Antioxidant supplements for preventing gastrointestinal cancers. The Cochrane Database of Systematic Reviews, 3, CD004183. https://doi.org/10.1002/14651858.CD004183.pub3

Bruce, D., Ooi, J. H., Yu, S., \& Cantorna, M. T. (2010). Vitamin D and host resistance to infection? Putting the cart in front of the horse. Experimental Biology and Medicine, 235(8), 921-927. https://doi.org/10.1258/ebm.2010.010061

Caccialanza, R., Laviano, A., Lobascio, F., Montagna, E., Bruno, R., Ludovisi, S., Corsico, A. G., Di Sabatino, A., Belliato, M., Calvi, M., Iacona, I., Grugnetti, G., Bonadeo, E., Muzzi, A., \& Cereda, E. (2020, June 1). Early nutritional supplementation in non-critically ill patients hospitalized for the 2019 novel coronavirus disease (COVID-19): Rationale and feasibility of a shared pragmatic protocol. Nutrition. https://doi.org/10.1016/j.nut.2020.110835

Calder, P. C., Carr, A. C., Gombart, A. F., \& Eggersdorfer, M. (2020, April 23). Optimal Nutritional Status for a Well-Functioning Immune System Is an Important Factor to Protect against Viral Infections. Nutrients, 12(4), 1181. https://doi.org/10.3390/nu12041181

Carr, A. C., Pullar, J. M., Bozonet, S. M., \& Vissers, M. C. M. (2016). Marginal ascorbate status (Hypovitaminosis C) results in an attenuated response to vitamin C supplementation. Nutrients, 8(6). https://doi.org/10.3390/nu8060341

Childs, C. E., Calder, P. C., \& Miles, E. A. (2019). Diet and immune function. Nutrients, 11(8). https://doi.org/10.3390/nu11081933

Corvalán, C., Garmendia, M. L., Jones-Smith, J., Lutter, C. K., Miranda, J. J., Pedraza, L. S., Popkin, B. M., Ramirez-Zea, M., Salvo, D., \& Stein, A. D. (2017). Nutrition status of children in Latin America. Obesity Reviews, 18(Suppl Suppl 2), 7-18. https://doi.org/10.1111/obr.12571

Crooke, S. N., Ovsyannikova, I. G., Poland, G. A., \& Kennedy, R. B. (2019). Immunosenescence and human vaccine immune responses. Immunity \& Ageing, 16(1). https://doi.org/10.1186/s12979-019-0164-9

Dewey, K. G., Yang, Z., \& Boy, E. (2009). Systematic review and meta-analysis of home fortification of complementary foods. Maternal \& Child Nutrition, 5(4), 283-321.

Dietary Reference Intakes for Vitamin A, Vitamin K, Arsenic, Boron, Chromium, Copper, Iodine, Iron, Manganese, Molybdenum, Nickel, Silicon, Vanadium, and Zinc. (2001). In Dietary Reference Intakes for Vitamin A, Vitamin K, Arsenic, Boron, Chromium, Copper, Iodine, Iron, Manganese, Molybdenum, Nickel, Silicon, Vanadium, and Zinc. National Academies Press. https://doi.org/10.17226/10026

Ebadi, M., \& Montano-Loza, A. J. (2020). Perspective: improving vitamin D status in the management of COVID-19. In European Journal of Clinical Nutrition (Vol. 74, Issue 6, pp. 856-859). Springer Nature. https://doi.org/10.1038/s41430-020-0661-0

Farias, P. K. S., Prates, R. P., da Silva, N., de Souza, S. A., \& Pereira, M. M. (n.d.). Estratégia De Fortificação Da Alimentação Infantil Com Micronutrientes Em Pó-Nutrisus.

Fidelis, C. M. F., \& Osório, M. M. (2007). Dietary intake of macro and micronutrients by children under 5 years of age in the State of Pernambuco, Brazil. Revista Brasileira de Saude Materno Infantil, 7(1), 63-74. https://doi.org/10.1590/s1519-38292007000100008 
Fischer Walker, C. L., Ezzati, M., \& Black, R. E. (2009). Global and regional child mortality and burden of disease attributable to zinc deficiency. European Journal of Clinical Nutrition, 63(5), 591-597. https://doi.org/10.1038/ejcn.2008.9

Gombart, A. F., Pierre, A., \& Maggini, S. (2020). A review of micronutrients and the immune system-working in harmony to reduce the risk of infection. Nutrients, 12(1). https://doi.org/10.3390/nu12010236

Grosso, G., Bei, R., Mistretta, A., Marventano, S., Calabrese, G., Masuelli, L., Giganti, M. G., Modesti, A., Galvano, F., \& Gazzolo, D. (2013). Effects of vitamin C on health: A review of evidence. Frontiers in Bioscience, 18(3), 1017-1029. https://doi.org/10.2741/4160

Guillin, O. M., Vindry, C., Ohlmann, T., \& Chavatte, L. (2019). Selenium, selenoproteins and viral infection. Nutrients, 11(9). https://doi.org/10.3390/nu11092101

Hemilä, H., \& Chalker, E. (2013). Vitamin C for preventing and treating the common cold. Cochrane Database of Systematic Reviews, 2013(1). https://doi.org/10.1002/14651858.CD000980.pub4

Hewison, M. (2010). Vitamin D and the immune system: New perspectives on an old theme. Endocrinology and Metabolism Clinics of North America, 39(2), 365-379. https://doi.org/10.1016/j.ec1.2010.02.010

Himoto, T., \& Masaki, T. (2018). Associations between zinc deficiency and metabolic abnormalities in patients with chronic liver disease. Nutrients, 10(1). https://doi.org/10.3390/nu10010088

Hoeger, J., Simon, T. P., Beeker, T., Marx, G., Haase, H., \& Schuerholz, T. (2017). Persistent low serum zinc is associated with recurrent sepsis in critically ill patients - A pilot study. PLoS ONE, 12(5). https://doi.org/10.1371/journal.pone.0176069

Hoffmann, P. R., \& Berry, M. J. (2008). The influence of selenium on immune responses. Molecular Nutrition and Food Research, 52(11), 1273-1280. https://doi.org/10.1002/mnfr.200700330

Ilie, P. C., Stefanescu, S., \& Smith, L. (2020). The role of vitamin D in the prevention of coronavirus disease 2019 infection and mortality. Aging Clinical and Experimental Research, 32(7), 1195-1198. https://doi.org/10.1007/s40520-020-01570-8

Kańtoch, M., Litwińska, B., Szkoda, M., \& Siennicka, J. (2002). Importance of vitamin A deficiency in pathology and immunology of viral infections. Roczniki Panstwowego Zakladu Higieny, 53(4), 385.

Kostermans, D., Simadibrata, M., Hasan, I., \& Budiyani, L. (2014). The Effect of Zinc Supplementation in Adult Patients with Acute Diarrhea. Indonesian Journal of Gastroenterology, Hepatology, and Digestive Endoscopy, 15(2), 83-87. https://doi.org/10.24871/152201483-87

Krinsky, N. I., Beecher, G. R., Burk, R. F., Chan, A. C., Erdman, j J. W., Jacob, R. A., Jialal, I., Kolonel, L. N., Marshall, J. R., \& Taylor Mayne, P. R. L. (2000). Dietary reference intakes for vitamin $\mathrm{C}$, vitamin $\mathrm{E}$, selenium, and carotenoids. Institute of Medicine.

Kumssa, D. B., Joy, E. J. M., Ander, E. L., Watts, M. J., Young, S. D., Walker, S., \& Broadley, M. R. (2015). Dietary calcium and zinc deficiency risks are decreasing but remain prevalent. Scientific Reports, 5. https://doi.org/10.1038/srep10974

Leung, C. (2020). Risk factors for predicting mortality in elderly patients with COVID-19: A review of clinical data in China. Mechanisms of Ageing and Development, 188. https://doi.org/10.1016/j.mad.2020.111255

Lima, L. W., Stonehouse, G. C., Walters, C., Mehdawi, A. F. El, Fakra, S. C., \& Pilon-Smits, E. A. H. (2019). Selenium Accumulation, Speciation and Localization in Brazil Nuts (Bertholletia excelsa H.B.K.). Plants, 8(8), 289. https://doi.org/10.3390/plants8080289

Machado, J., Silvestre, S., Marchini, J., \& Vannuchi, H. (2009). Manual de Procedimentos em Nutrologia. Guanabara Koogan.

Mafra, D., \& Cozzolino, S. M. F. (2004). The importance of zinc in human nutrition. Revista de Nutricao, 17(1), 79-87. https://doi.org/10.1590/s141552732004000100009

Maggini, S., Pierre, A., \& Calder, P. C. (2018). Immune function and micronutrient requirements change over the life course. Nutrients, 10(10). https://doi.org/10.3390/nu10101531

Maret, W., \& Sandstead, H. H. (2006). Zinc requirements and the risks and benefits of zinc supplementation. Journal of Trace Elements in Medicine and Biology, 20(1), 3-18. https://doi.org/10.1016/j.jtemb.2006.01.006

Martineau, A. R., Jolliffe, D. A., Hooper, R. L., Greenberg, L., Aloia, J. F., Bergman, P., Dubnov-Raz, G., Esposito, S., Ganmaa, D., Ginde, A. A., Goodall, E. C., Grant, C. C., Griffiths, C. J., Janssens, W., Laaksi, I., Manaseki-Holland, S., Mauger, D., Murdoch, D. R., Neale, R., ... Camargo, C. A. (2017). Vitamin D supplementation to prevent acute respiratory tract infections: Systematic review and meta-analysis of individual participant data. BMJ (Online), 356. https://doi.org/10.1136/bmj.i6583

Mocchegiani, E., Romeo, J., Malavolta, M., Costarelli, L., Giacconi, R., Diaz, L. E., \& Marcos, A. (2013). Zinc: Dietary intake and impact of supplementation on immune function in elderly. Age, 35(3), 839-860. https://doi.org/10.1007/s11357-011-9377-3

Moghaddam, A., Heller, R. A., Sun, Q., Seelig, J., Cherkezov, A., Seibert, L., Hackler, J., Seemann, P., Diegmann, J., Pilz, M., Bachmann, M., Minich, W. B., \& Schomburg, L. (2020). Selenium deficiency is associated with mortality risk from COVID-19. Nutrients, 12(7), 1-13. https://doi.org/10.3390/nu12072098

Nagib, A., Aldemar, A., \& Castro, A. (n.d.). Revisão Sistemática da Literatura e Metanálise: a melhor forma de evidência para tomada de decisão em saúde e a maneira mais rápida de atualização terapêutica. Retrieved January 26, 2021, from http://hiru.mcmaster.ca/cochrane

Nogueira, T. B. de B., Oliveira, T. A. de, Medina, T. de S., Nascimento, F. R., Nascimento, T. P. do, \& Ferreira, M. S. L. (2019). Acessibilidade, biodisponibilidade e consumo de alimentos ricos em carotenoides e vitamina A em crianças de até 5 anos. In SEMEAR: Revista de Alimentação, Nutrição e Saúde (Vol. 1, Issue 1). http://www.seer.unirio.br/index.php/ralnuts/article/view/8308 
Oh, S. J., Lee, J. K., \& Shin, O. S. (2019). Aging and the immune system: The impact of immunosenescence on viral infection, immunity and vaccine immunogenicity. Immune Network, 19(6). https://doi.org/10.4110/in.2019.19.e37

Organization, W. H. (2007). Preventing and controlling micronutrient deficiencies in populations affected by an emergency. Joint Statement by the WHO/FAO/UNICEF. Geneva: WHO.

Organization, W. H. (2010). Diarrhoea treatment guidelines including new recommendations for the use of ORS and zinc suppleme ntation for clinic-based healthcare workers. Version current January 2005. In Available from: whqlibdoc. who. int/publications/2005/a85500. pdf.

Organization, W. H., \& UNICEF. (2006). Johns Hopkins Bloomberg School of Public Health; USAID. Implementing the new recommendations on the clinical management of diarrhea. Guidelines for policy makers and programme managers. Geneva, Switzerland: WHO Press.

Padovani, R. M., Amaya-Farfán, J., Colugnati, F. A. B., \& Domene, S. M. Á. (2006). Dietary reference intakes: Application of tables in nutritional studies. Revista de Nutricao, 19(6), 741-760. https://doi.org/10.1590/S1415-52732006000600010

Pae, M., \& Wu, D. (2017). Nutritional modulation of age-related changes in the immune system and risk of infection. Nutrition Research, 41, 14-35. https://doi.org/10.1016/j.nutres.2017.02.001

Pawelec, G. (2018). Age and immunity: What is “immunosenescence”? Experimental Gerontology, 105, 4-9. https://doi.org/10.1016/j.exger.2017.10.024

Pedraza, D. F., Rocha, A. C. D., \& Sousa, C. P. C. (2013). Crescimento e deficiências de micronutrientes: perfil das crianças assistidas no núcleo de creches do governo da Paraíba, Brasil. Ciência \& Saúde Coletiva, 18, 3379-3390.

Read, S. A., Obeid, S., Ahlenstiel, C., \& Ahlenstiel, G. (2019). The Role of Zinc in Antiviral Immunity. Advances in Nutrition, 10(4), 696-710. https://doi.org/10.1093/advances/nmz013

Ruel-Bergeron, J. C., Stevens, G. A., Sugimoto, J. D., Roos, F. F., Ezzati, M., Black, R. E., \& Kraemer, K. (2015). Global update and trends of hidden hunger, 1995-2011: The hidden hunger Index. PLOS ONE, 10(12). https://doi.org/10.1371/journal.pone.0143497

Rükgauer, M., Klein, J., \& Kruse-Jarres, J. D. (1997). Reference values for the trace elements copper, manganese, selenium, and zinc in the serum/plasma of children, adolescents, and adults. Journal of Trace Elements in Medicine and Biology, 11(2), 92-98. https://doi.org/10.1016/S0946-672X(97)80032-6

Schwingshackl, L., Boeing, H., Stelmach-Mardas, M., Gottschald, M., Dietrich, S., Hoffmann, G., \& Chaimani, A. (2017). Dietary Supplements and risk of cause-specific death, cardiovascular disease, and cancer: A systematic review and meta-analysis of primary prevention trials. Advances in Nutrition, 8(1), 2739. https://doi.org/10.3945/an.116.013516

Semba, R. D. (1999). Vitamin A and immunity to viral, bacterial and protozoan infections. Proceedings of the Nutrition Society, 58(3), 719-727. https://doi.org/10.1017/S0029665199000944

Silva, L. L. S. da. (2017). Fortificação da alimentação complementar com múltiplos micronutrientes em pó na prevenção da anemia e no estado nutricional de vitamina A em crianças da Atenção Básica.

Singer, P., Berger, M. M., Van den Berghe, G., Biolo, G., Calder, P., Forbes, A., Griffiths, R., Kreyman, G., Leverve, X., \& Pichard, C. (2009). ESPEN Guidelines on Parenteral Nutrition: Intensive care. Clinical Nutrition, 28(4), 387-400. https://doi.org/10.1016/j.clnu.2009.04.024

Singer, P., Blaser, A. R., Berger, M. M., Alhazzani, W., Calder, P. C., Casaer, M. P., Hiesmayr, M., Mayer, K., Montejo, J. C., Pichard, C., Preiser, J. C., van Zanten, A. R. H., Oczkowski, S., Szczeklik, W., \& Bischoff, S. C. (2019). ESPEN guideline on clinical nutrition in the intensive care unit. Clinical Nutrition, 38(1), 48-79. https://doi.org/10.1016/j.clnu.2018.08.037

Siva, S., Rubin, D. T., Gulotta, G., Wroblewski, K., \& Pekow, J. (2017). Zinc deficiency is associated with poor clinical outcomes in patients with inflammatory bowel disease. Inflammatory Bowel Diseases, 23(1), 152-157. https://doi.org/10.1097/MIB.0000000000000989

Ströhle, A., \& Hahn, A. (2009). Importance of micronutrients for immunity. Prevention and therapeutic aspects. MMW Fortschritte Der Medizin, 151(Supplement 3), 133-141.

te Velthuis, A. J. W., van den Worml, S. H. E., Sims, A. C., Baric, R. S., Snijder, E. J., \& van Hemert, M. J. (2010). Zn2+ inhibits coronavirus and arterivirus RNA polymerase activity in vitro and zinc ionophores block the replication of these viruses in cell culture. PLoS Pathogens, 6(11). https://doi.org/10.1371/journal.ppat.1001176

Teng, J., Pourmand, A., \& Mazer-Amirshahi, M. (2018). Vitamin C: The next step in sepsis management? Journal of Critical Care, 43, 230-234. https://doi.org/10.1016/j.jcrc.2017.09.031

Trottier, C., Colombo, M., Mann, K. K., Miller, W. H., \& Ward, B. J. (2009). Retinoids inhibit measles virus through a type I IFN-dependent bystander effect. The FASEB Journal, 23(9), 3203-3212. https://doi.org/10.1096/fj.09-129288

Uchide, N., Ohyama, K., Bessho, T., Yuan, B., \& Yamakawa, T. (2002). Effect of antioxidants on apoptosis induced by influenza virus infection: Inhibition of viral gene replication and transcription with pyrrolidine dithiocarbamate. Antiviral Research, 56(3), 207-217. https://doi.org/10.1016/S0166-3542(02)00109-2

Wessells, K. R., \& Brown, K. H. (2012). Estimating the Global Prevalence of Zinc Deficiency: Results Based on Zinc Availability in National Food Supplies and the Prevalence of Stunting. PLOS ONE, 7(11). https://doi.org/10.1371/journal.pone.0050568

West, C. E., Sijtsma, S. R., Kouwenhoven, B., Rombout, J. H. W. M., \& Van der Zijpp, A. J. (1992). Epithelia-damaging virus infections affect vitamin A status in chickens. Journal of Nutrition, 122(2), 333-339. https://doi.org/10.1093/jn/122.2.333

Zaatari, S., Radecki, R. P., \& Spiegel, R. (2020). Vitamin C May Not Help Your Cold, but Can It Treat Sepsis and Acute Respiratory Distress Syndrome?: March 2020 Annals of Emergency Medicine Journal Club. Annals of Emergency Medicine, 75(3), 455-457. https://doi.org/10.1016/j.annemergmed.2020.01.014 
Research, Society and Development, v. 10, n. 2, e7010212259, 2021

(CC BY 4.0) | ISSN 2525-3409 | DOI: http://dx.doi.org/10.33448/rsd-v10i2.12259

Zemb, P., Bergman, P., Camargo, C. A., Cavalier, E., Cormier, C., Courbebaisse, M., Hollis, B., Joulia, F., Minisola, S., Pilz, S., Pludowski, P., Schmitt, F., Zdrenghea, M., \& Souberbielle, J. C. (2020). Vitamin D deficiency and the COVID-19 pandemic. Journal of Global Antimicrobial Resistance, $22,133-134$. https://doi.org/10.1016/j.jgar.2020.05.006

Zhang, J., Taylor, E. W., Bennett, K., Saad, R., \& Rayman, M. P. (2020). Association between regional selenium status and reported outcome of COVID-19 cases in China. American Journal of Clinical Nutrition, 111(6), 1297-1299. https://doi.org/10.1093/ajen/nqaa095

Zhang, L., \& Liu, Y. (2020). Potential interventions for novel coronavirus in China: A systematic review. Journal of Medical Virology, 92(5), 479-490. https://doi.org/10.1002/jmv.25707

Zumla, A., Hui, D. S., Azhar, E. I., Memish, Z. A., \& Maeurer, M. (2020). Reducing mortality from 2019-nCoV: host-directed therapies should be an option. The Lancet, 395(10224), e35-e36. https://doi.org/10.1016/S0140-6736(20)30305-6 